\title{
Program of the Subcommittee on Construction and Building
}

Richard N. Wright, Co-Chair

Arthur H. Rosenfeld, Co-Chair

Andrew J. Fowell, Secretariat 



\section{Program of the Subcommittee on Construction and Building}

Richard N. Wright, Co-Chair

Arthur H. Rosenfeld, Co-Chair

Andrew J. Fowell, Secretariat

July 1994
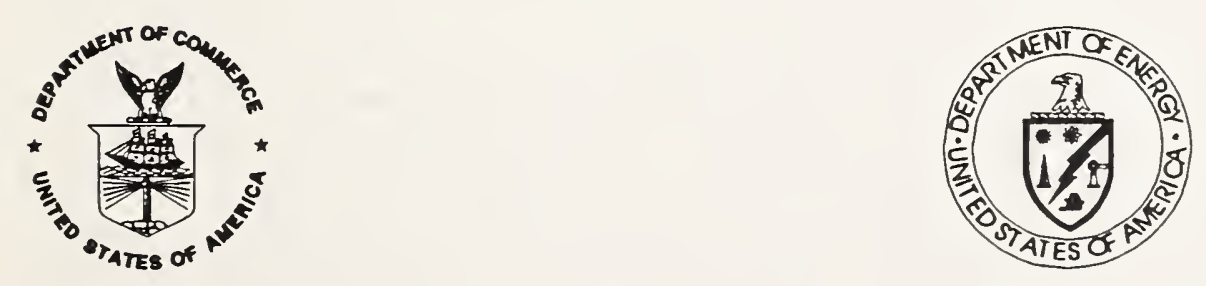

U.S. Department of Commerce

Ronald H. Brown, Secretary

Technology Administration

Mary L. Good, Under Secretary for Technology

National Institute of Standards and Technology

Arati A. Prabhakar, Director
U.S. Department of Energy Hazel R. O'Leary, Secretary Energy Efficiency and Renewable Energy Christine A. Ervine, Assistant Secretary 


\section{ABSTRACT}

The President has established the National Science and Technology Council (NSTC), a cabinet-level group charged with setting Federal science and technology policy, to coordinate and prioritize R\&D and deployment strategies across a broad cross-section of public and private interests. It has established nine research and development committees, including the Committee on Civilian Industrial Technology (CCIT) to collaborate with the private sector in developing a comprehensive national technology policy. The purpose of CCIT is to enhance the international competitiveness of U.S. industry through Federal technology policies and programs. The Subcommittee on Construction and Building coordinates and defines priorities for Federal research, development and deployment related to the industries that produce, operate and maintain constructed facilities, including buildings and infrastructure.

The Subcommittee on Construction and Building has studied research priorities including those expressed by the construction industry and defined two priority thrusts: better constructed facilities and health and safety of the construction workforce. Goals for Better Constructed Facilities are: 50\% reduction in delivery time, $50 \%$ reduction in costs of operation and maintenance, $30 \%$ increase in productivity and comfort, $50 \%$ fewer occupant related illnesses and injuries, 50\% less waste and pollution, and 50\% more durable and flexible. The goal for Health and Safety of Construction Workforce is a 50\% reduction in job related illnesses and injuries.

These goals will be achieved with improved housing affordability, and where possible with reduced construction, operation and maintenance costs (both initial and life cycle). The baseline for the improvements is today's business practices.

Construction is a giant industry. In 1993, new construction put in place amounted to $\$ 470$ billion, $8 \%$ of the GDP, and provided employment to 6 million persons. To forge partnership with industry to strengthen American's competitiveness in this sector, the program and goals for Construction and Building were reviewed with a focus group of industry leaders convened on April 5, 1994, by the Civil Engineering Research Foundation. The response of the focus group is described in the Construction Industry Whitepaper "Innovation in the U.S. Construction Industry: An Essential Component for America's Economic Prosperity and Well Being." The white paper is an industry perspective of methods and means that, if jointly supported and implemented by the public and private sector, promise to transform the construction sector into the high technology/high skill sector America requires. Construction industry leaders strongly endorse the ambitious goals recently established by the NSTC Subcommittee on Construction and Building. Industry leaders urge expanded dialogue and, most important, the immediate initiation of actions. The Subcommittee is in the process of developing strategies to involve all interested groups to accomplish its goals. 
The Administration has assigned priorities for Research and Development for the FY 1996 budget to Construction and Building as "Activities that support the residential/commercial building construction industry and its suppliers in the development of advanced technologies aimed at increasing the productivity of construction, improving product quality (including energy efficiency and improved indoor air quality), use of renewable resources, and increased worker health and safety." 
PROGRAM OF THE

SUBCOMMITTEE ON CONSTRUCTION AND BUILDING

CONTENTS

PAGE

ABSTRACT

1. INTRODUCTION

2. PRESIDENT'S TECHNOLOGY POLICY GOALS

3. BACKGROUND ON THE CONSTRUCTION INDUSTRY AND CONSTRUCTED FACILITIES

4. ROLE OF THE PROPOSED PROGRAM ON CONSTRUCTION AND BUILDING

5. MISSION FOR THE SUBCOMMITTEE ON CONSTRUCTION AND BUILDING

6. PRIORITY SETTING PROCESS AND CRITERIA

7. MECHANISMS FOR WORKING WITH INDUSTRY

8. SUPPORT FOR TECHNOLOGY DEPLOYMENT

9. PROGRAM MILESTONES AND METRICS

10. BUDGET AUTHORITY FOR FY 1994 AND FY 1995

Appendix 1. CERF WHITEPAPER

A. 1.1

Appendix 2. ROSTER OF THE CONSTRUCTION AND BUILDING SUBCOMMITTEE

A. 2.1

Appendix 3. CONSTRUCTION COMMUNITY ORGANIZATIONS

A. 3.1 


\section{INTRODUCTION}

The National Science and Technology Council (NSTC), a cabinet-level group charged with setting Federal technology policy, will coordinate R\&D strategies across a broad cross-section of public and private interests. It has established nine research and development committees, including the Committee on Civilian Industrial Technology (CCIT), to collaborate with the private sector in developing a comprehensive national technology policy.

The purpose of CCIT is to enhance the international competitiveness of U.S. industry through Federal technology policies and programs. CCIT will provide a mechanism for coordinating national policy for this purpose across agency boundaries and will serve as a center for interagency exchange of information. CCIT will work closely with industrial leaders in determining research and development directions and setting priorities.

The Subcommittee on Construction and Building (C\&B) of CCIT deals with Federal technology policies and programs related to the industries that conduct R\&D, and produce, operate and maintain constructed facilities including buildings and infrastructure. This Program Description describes cooperative activities of the Federal agencies that participate in $C \& B$, as performers of $R \& D$ for building and construction or owners and users of constructed facilities, and the industry groups concerned as users of, producers of, or suppliers for constructed facilities.

\section{PRESIDENT'S TECHNOLOGY POLICY GOALS}

[from: "Technology for America's Economic Growth, A New Direction to Build Economic Strength," President Clinton and Vice President Gore, February 22, 1993]

\section{Goals Cited by the Committee for Civilian Industrial Technology (CCIT)}

Forge partnerships with industry to strengthen America's industrial competitiveness and create jobs.

Balance funding for civilian and dual-use R\&D with funding for purely military R\&D.

Make environmental protection and energy efficiency fully consistent with other business objectives.

Construction-related Citations from "Technology for America's Economic Growth"

- "technology matters --- to a construction industry that builds highquality affordable housing;" (p. 2) 
- "Federal agency purchasing policies designed to foster early markets for innovative products and services that contribute to national goals" (p. 4)

- "accelerated investment in advanced manufacturing technologies that promote U.S. industrial competitiveness and that build on, rather than minimize, worker skills" (p. 5)

- "investments in energy-efficient Federal buildings to reduce wasteful energy expenses and encourage the adoption of innovative, energy efficient technology" (p. 6)

- "programs will be encouraged in the development of -. new construction technologies" (p. 7)

- "review the Nation's regulatory "infrastructure" to ensure that unnecessary obstacles to technical innovation are removed and that priorities are attached to programs introducing technology to help reduce the cost of regulatory compliance" ( $p .13$ )

- "consider establishing a integrated program of research designed to enhance the performance and longevity of the existing infrastructure" (p. 18)

- "exploring new assessment technologies for more accurately assessing the expected life of existing public infrastructure-.-. Since current assessment techniques are so unreliable, engineering decisions must include significant room for error and costly fail safe features. The data made available by nondestructive evaluation and monitoring could be used to schedule better an ongoing program of cost effective maintenance and rehabilitation." "Supporting renewal engineering programs, which target materials and construction methods that would lower the cost of rehabilitating and repairing structures." (p. 19)

- "agencies should evaluate bids based on their ability to minimize life cycle cost rather than acquisition cost, including environmental, health and safety costs borne by the public" (p. 23)

- "agencies should use performance-based contracting strategies that give contractors the design freedom and financial incentive to be innovative and efficient" (p. 23) 


\section{BACKGROUND ON CONSTRUCTION INDUSTRY AND CONSTRUCTED FACILITIES}

Construction is one of the Nation's largest industries and a critical asset for enhancing the international competitiveness of U.S. industry. In 1993, new construction put in place amounted to $\$ 470$ billion, $8 \%$ of the GDP, and provided employment for 6 million persons. The breakdown of new construction put in place in 1993 is: residential 44\%; commercial, institutional and industrial 28\%; public works $28 \%$. (When renovation is included, construction probably amounts to about $\$ 800$ billion annually, $13 \%$ of GDP, and 10 million jobs.) Constructed facilities shelter and support most human activities. Their quality affects the competitiveness of U.S. industry, the safety and quality of life of the people, and environmental quality. Moreover, the quality of construction strongly affects the wealth of the Nation; over fiveeighths of the Nation's fixed reproducible wealth is invested in constructed facilities.

For U.S. industries to compete internationally, their technologies must be superior and their production facilities must be more cost effective than their competitors'.

Once built and operating, buildings consume annually $\$ 220$ billion of energy (nearly half our total U.S. energy bill), of which $\$ 150$ billion goes for electricity ( $80 \%$ of all electric revenues). Modernization could save $\$ 100$ billion/year, with profitable payback times, and simultaneously improve comfort and thus make our work force more productive.

Construction is a giant, but disaggregated, industry. Small enterprises predominate in construction. There usually is a unique team (owner, architect, structural engineer, general contractor, specialty contractors, etc.) for each construction project. Each participant may have several simultaneous projects. The team for each project usually never has worked together before, and will not again.

This disaggregated structure allows the construction industry to adapt to large, rapid changes in the volume of construction work. This disaggregated nature also gives construction great flexibility for innovation. A small organization can master a new technology or produce a new product, and convince an owner, designer or general contractor to try the innovation on a particular project, without having to break into a highly centralized, monolithic system. However, interfaces with other products or practices, liability concerns and regulations are barriers to innovation.

Construction includes the whole life of the project: initial planning and programming, design, manufacturing and site construction, occupancy and maintenance, condition assessment, retrofit and renovation or removal. Figure 1 shows the life cycle of constructed facilities. This whole life viewpoint is necessary to give realistic attention to values and costs of constructed facilities. For instance, for an office building, the annual operating cost, including salaries of occupants, roughly equals the initial 
construction cost. The primary value comes from the productivity of the occupants, which depends on the capability of the building to meet user needs throughout its useful life.

The average level of new construction put in place over the last decade has been $8 \%$ of the GNP which is down from the $11.9 \%$ attained in 1966 . In contrast, Japan's is about $16 \%$ of GNP. The effects of the low U.S. investment are seen in the condition of U.S. constructed civil infrastructure systems: according to the National Council on Public Works Improvement "the quality of America's infrastructure today is barely adequate to meet current requirements and insufficient to meet the demands of future economic growth." Effects also are seen on the productive capabilities of commerce and industry: according to David Aschauer "the decline in infrastructure investment can explain half or more of the productivity decline in the U.S."

Technical leadership is essential to competitiveness of the U.S. construction industry. A survey of leading U.S. and foreign design and construction firms, published in Cost Engineering, obtained their views of international leadership in construction technologies. Nineteen areas of construction technology were considered; the U.S. was assessed by the respondents to lead in just four, be even in one and to trail in fourteen. Specific instances of foreign leadership were cited in innovative materials, tunneling, underground piping, robotics and earthquake engineering.

Comparisons of U.S. and foreign construction research, development and application efforts indicate the U.S. will fall further behind in technology and competitiveness unless actions are taken to change present trends. U.S. research support for construction technology is very limited compared to other nations and industries. A 1993 study by the Civil Engineering Research Foundation indicates that construction R\&D is only $0.5 \%$ of construction value. Private sector $R \& D$ for construction focuses on product development from which research investments can be recouped in the marketplace. Most technology development work by design and construction firms is expensed to specific projects rather than reported as research and development, but these efforts are much smaller than the $1 \%$ of gross income reported by Japanese designconstruction firms.

As with other giant, disaggregated industries, such as agriculture and health, Federal support is dependent upon for nonproprietary research that provides the knowledge base for private innovation, environmental quality and public health and safety. In 1992 Federal funding for health research amounted to $\$ 9.8$ billion. In contrast, the Civil Engineering Research Foundation could identify about $\$ 1.3$ billion for annual Federal research for construction and civil infrastructure. U.S. technological leadership is unquestioned in health care. The health care industry has increased its share of gross national product from $7.4 \%$ in 1970 to $13.2 \%$ in 1991 , while new construction has about $8 \%$ in recent years. 
The European Union and the European Free Trade Association permit free flow of construction products and services within Western Europe. This is the world's richest single market of 372 million persons. European standards and codes are used by the member countries for acceptance of products and services, and a European product approval system allows products made, tested and approved in one country to be used in all without further testing or approvals. In all of this effort there is little U.S. involvement or input. However, these actions may have profound impact on the U.S. The European standards and product approval system may be a major barrier to U.S. exports of construction products and services, and may influence international standards for other markets to the detriment of U.S. interests. In order to gain access to the European market and other foreign markets, the U.S. will need comparable, nationally-recognized practices for acceptance of construction products and services.

A barrier in international competitiveness is the cost of injuries and diseases among construction workers. Although the construction workforce represents about $6 \%$ of the Nation's workforce, it is estimated that the construction industry pays for about one-third of the Nation's workers' compensation. Workers' compensation insurance premiums range from 7 to $100 \%$ of payroll in the construction industry. A major cost is attributable to musculoskeletal injuries (sprains and strains). The means and methods of construction could be improved through ergonomics (redesign of the equipment and the job) to reduce this cost.

In terms of international competition, fatality rates provide one measure for comparison. In the United States the fatality rate for construction workers is 14.0 fatalities per 100,000 workers (the national average is 7.0 ), in the Netherlands its is 3.3, and in Sweden it is 6.0. The U.S. figure includes the self-employed.

\section{ROLE OF PROGRAM ON CONSTRUCTION AND BUILDING}

The program provides a vision for the construction and building industries in which:

High quality constructed facilities support the competitiveness of U.S. industry and everyone's quality of life.

U.S. industry leads in quality and economy in the global market for construction products and services. 
The construction industry and constructed facilities are energy efficient, environmentally benign, safe and healthful and sustainable in use of resources.

Natural and manmade hazards do not cause disasters.

Intelligent renewal, a process that cost effectively uses limited economic, material, and human resources, is applied to rebuilding America.

\section{MISSION FOR THE SUBCOMMITTEE ON CONSTRUCTION AND BUILDING}

Enhance the competitiveness of U.S. industry, public safety and environmental quality through research and development, in cooperation with U.S. industry, labor, and academia, for improvement of the life cycle performance of constructed facilities.

\section{PRIORITY SETTING PROCESS AND CRITERIA}

Priorities are defined by working with Federal agencies, industry and academia to define the knowledge the construction industry needs to achieve CCIT goals:

Strengthen America's industrial competitiveness and create jobs.

Balance funding for civilian and dual-use R\&D with funding for purely military R\&D.

Make environmental protection, safety, health, and energy efficiency fully consistent with other business objectives.

Recommendations for Federal programs addressing priority needs will be based on partnerships with industry and academia so that private and public funds are used appropriately and the best $R \& D$ resources are applied to meeting the knowledge needs.

Based on research priorities expressed by the construction industry the following two priority thrusts were defined by $C \& B$ for further discussion with industry for focus of R\&D in the construction and building area for FY 1996 initiatives. Significant and challenging, but feasible, goals were established for the improvement of the life cycle performance of constructed facilities. 


\section{Better Constructed Facilities}

- $50 \%$ reduction in delivery time

- $50 \%$ reduction in operation and maintenance

- $30 \%$ increase in productivity and comfort

- $50 \%$ fewer occupant related illnesses and injuries

- $50 \%$ less waste and pollution

- $50 \%$ more durability and flexibility

\section{Health and Safety of Construction Workforce}

- $50 \%$ reduction in job related illnesses and injuries

These goals will be achieved with improved housing affordability, and where possible with reduced other costs, both initial and life cycle. The baseline for the above improvements will be today's business practices.

The program and goals were reviewed with a focus group of industry leaders convened on April 5, 1994, by the Civil Engineering Research Foundation. The response of the focus group is described in the Construction Industry Whitepaper, "Innovation in the U.S. Construction Industry: An Essential Component for America's Economic Prosperity and Well-Being." (Appendix 1) The white paper is an industry perspective of methods and means that, if jointly supported and implemented by the public and private sector, promise to transform the construction sector into the high technology/high skill sector America requires. Construction industry leaders strongly endorse the ambitious goals, urge expanded dialogue and, most important, the immediate initiation of industry-Federal government cooperative efforts to refine and implement actions.

In the May 6, 1994, memorandum from John Gibbons, President's Science Advisory, and Leon Panetta, Director, OMB, the White House gave priorities to Construction and Building for FY 1996 Research and Development: "Activities that support the residential/commercial building construction industry and its suppliers in the development of advanced technologies aimed at increasing the productivity of construction, improving product quality (including energy efficiency and improved indoor air quality), use of renewable resources, and increased worker health and safety." 


\section{MECHANISMS FOR WORKING WITH INDUSTRY}

Representatives from the following agencies currently form the Subcommittee:

Department of Commerce, Co-chair

Department of Energy, Co-chair

Department of Agriculture

Department of Defence

Department of Housing and Urban Development

Department of Health and Human Services

Department of Labor

Department of Transportation

Department of Veterans Affairs

General Services Administration

Environmental Protection Agency

National Science Foundation

National Aeronautics and Space Administration

The Subcommittee includes those agencies supporting and performing R\&D and those that can effect technology deployment through the procurement process. The current Subcommittee roster is shown in Appendix 2. Small, well qualified working groups have been formed within the Subcommittee to address R\&D and technology deployment in cooperation with industry and related groups.

Important industry groups include:

Owners, Developers and Users

Architectural and Engineering Designers

Construction and Contracting Services

Labor

Suppliers of Materials and Equipment Manufacturers

Standards Development and Code Enforcement

Health, Environment, Safety and Emergency Response

Finance and Insurance

State and Local Governments

Universities and Research Organizations

These industry groups are represented by a variety of industry and professional organizations (Appendix 3) with which the Subcommittee on Construction and Building will collaborate in assessing needs and planning the Federal R\&D and technology deployment activities. The Subcommittee will continue to use CERF as a focal point and will work directly with other industry groups as the need arises. 


\section{SUPPORT FOR TECHNOLOGY DEPLOYMENT}

Four mechanisms are planned:

(1) Develop streamlined decision making information and communication capabilities to support collaboration among the diverse participants in each construction project.

(2) National voluntary standards, used for agreements between buyers and sellers and cited in codes and regulations, are the major, traditional mechanism for technology deployment in construction. In accord with OMB Circular A-119, "Federal Participation in the Development and Use of Voluntary Standards," Federal agencies' staff will participate actively in voluntary standardization to move $R \& D$ results to practice. Mechanisms will be explored for increased involvement by both public and private sectors in the international standards setting process to facilitate the acceptance of U.S. construction products and practices in international markets .

(3) A large proportion of the Nation's construction is Federal or federallyassisted or regulated. In accord with the President's technology policy goals:

"Federal agency purchasing policies designed to foster early markets for innovative products and services that contribute to national goals"

"investments in energy-efficient Federal buildings to reduce wasteful energy expenses and encourage the adoption of innovative, energy efficient technology"

"review the Nation's regulatory "infrastructure" to ensure that unnecessary obstacles to technical innovation are removed and that priorities are attached to programs introducing technology to help reduce the cost of regulatory compliance"

"agencies should evaluate bids based on their ability to minimize life cycle cost rather than acquisition cost, including environmental, health and safety costs borne by the public"

"agencies should use performance-based contracting strategies that give contractors the design freedom and financial incentive to be innovative and efficient" 
Federal programs for constructed facilities management and renovation, construction and construction assistance, and regulation of construction will be mechanisms to introduce beneficial new technologies to practice and demonstrate their effectiveness for private sector applications.

(4) Technology deployment programs of the Advanced Research Projects Agency, the National Institute of Standards and Technology, the U.S. Army Corps of Engineers, the Department of Transportation, and the Department of Energy will be used to develop technology transfer programs to provide strategic support to U.S. industry. Linkages with academia will be developed through the National Science Foundation Engineering Research Centers and individual/group researchers.

\section{PROGRAM MILESTONES AND METRICS}

The primary measures of success will be: expansion of domestic construction and building industries, increased U.S. share of the international construction and building products markets, and improvements in building performance, including reductions in energy consumption, and improvements in construction worker health and safety.

The following tentative milestones for the program goals will be tested with industry and Federal agencies:

\section{Better Constructed Facilities}

Identify and evaluate current innovative building technologies, encourage their use and demonstration in currently planned building projects, and plan implementation of successful technologies.

Synthesize advanced technologies addressing the program goals from available knowledge, and define specific research objectives.

Demonstrate research based, advanced technology which realizes the program goals in demonstration projects ready for occupancy. (1996-2001)

Implement new standards making these technologies normal practice. (2003) 
Health and Safety of Construction Workers

Identify construction practices of those companies with low injury records, incorporate and highlight such practices in currently planned building demonstration projects, and plan their general implementation. (1995)

Identify advanced state-of-the-art, safe, cost effective construction practices, and define specific research objectives. (1996)

Demonstrate and evaluate safe, cost effective construction practices. (1996-1999)

Implement new, research-based standards for construction practices. (2000)

The Subcommittee's own immediate plan and milestones are as follows:

1. Plan: Initial workplan incorporated into program description $5 / 13$ Continually update plan.

2. Meeting Schedules and Working Groups: To pursue this workplan the Subcommittee plans biweekly meetings for May, June, and July of 1994, and monthly meetings thereafter. (Meetings will be on Friday mornings at 9:00 a.m. - 5/13, 5/27, 6/10,6/24, 7/8, 7/22, 8/19, 9/16, 10/14, 11/18, 12/16.)

Working groups will be organized to address R\&D and enabling technologies, and technology deployment and non-technical barriers.

3. Subcommittee Brochure: To give interested parties an overview of the targets and work a small brochure will be developed from the Program Summary. 5/30. (The brochure will be updated periodically.)

4. Program Description: The program description will be produced as a report of the Subcommittee. 5/30. The program description will be updated periodically.)

5. Work with Industry: This is the most important aspect of the workplan. Industry policy support is vital to obtain the Federal funding. Industry investment in development and marketing of new products and services is essential to achieving the targets.

The focus group organized by CERF on $4 / 5$ was successful. The resulting whitepaper is Appendix 1. C\&B will continue work with CERF.

C\&B has identified key organizations (see Appendix 3), beyond CERF, that should be involved in the program, and will identify an individual

champion for each. $C \& B$ will then hold meetings with each of the groups of 
organizations to brief key persons and then begin collaboration in planning. $9 / 30$.

A Roundtable of leaders from industry and government will be planned to discuss the needs for and private/public collaboration in the program. Sponsorship by a leading construction publisher will be arranged so that key participants are attracted and the larger community is informed. A steering committee has been formed to organize a Workshop on Research and Implementation for Constructed Facilities. The workshop, involving leading thinkers from industry, academia and industry, will be held to critique and strengthen the draft private/public plan for research and implementation for constructed facilities to meet stated goals. 12/15

6. Coordinate with other NSTC committees: Strong coordination has been established with the following committees and subcommittees of the National Science and Technology Council.
Committee on Civilian Industrial Technology
Materials Subcommittee
Manufacturing Subcommittee, NSTC
Committee on Health, Safety and Food
Committee on Information and Communication R\&D
Committee on Environment and Natural Resources
Committee on Transportation R\&D

7. Relate R\&D and Barrier Removal to Goals: Technical needs and opportunities are the heart of $C \& B$ work. In cooperation with the private sector $C \& B$ will:

- Map its goals against needs and opportunities for beneficial innovations.

- Select the "short list" of R\&D thrusts.

- Use them to assess current $R \& D$ and to develop priority recommendations for FY96.

Non-technical issues have been identified as barriers to the use of new technology. In cooperation with the private sector $C \& B$ will:

- Map its goals against non-technical barriers 
- Select the "short 1ist" of most important non-technical barriers

- Plan how to relieve the barriers

- Address them in recommendations of $C \& B$ or through other organizations.

$C \& B$ plans to have a working taxonomy to relate $R \& D$ and the removal of non technical barriers by $6 / 24$

8. Deployment Opportunities:

Key to establishing technical leadership and creating jobs in the construction and building industry is to ensure that appropriate technical innovations are deployed.

$C \& B$ will search within Federal agencies and at meetings with private sector groups of organizations for technical innovations suitable for early deployment. $7 / 31$

C\&B will explore opportunities to demonstrate FY95 and FY96 technical innovations and the removal of barriers within federal construction and remodeling projects. $7 / 8$

$C \& B$ will identify information systems suitable for monitoring current research and delivering information on research results. 7/15

9. Report on Current Federal Research for Construction and Building: This report will be an "inventory" developed from data on FY94 and FY95 programs provided by agency representatives. A major part of $C \& B$ planning will be to focus this base R\&D on the C\&B goals. 7/29

10. Report Documenting Construction and Building Goals: This report is to describe $C \& B$ goals clearly and show by analysis that they are important and feasible. $8 / 31$ (C\&B will collect reference material that can be used to support the goals.)

11. Proposal for FY96 Budget in C\&B: This will summarize the workplan-related FY96 budget proposals for the agencies contributing to $C \& B$ the workplan. $8 / 31$

12. NSTC Report on Advanced Technologies for Constructed Facilities: This report will incorporate materials from the report describing the importance and feasibility of the goals, the inventory report, and the plan to back up the President's budget request. The report will also cite planned deployment activities and opportunities. 1/28/95 
13. Private sector Program Plan for Advanced Technologies for Constructed Facilities: This plan will be developed by the private sector with partial support from Federal funding provided by the agencies represented on the Subcommittee. 1/28/95

10. BUDGET AUTHORITY FOR FY 1994 AND FY 1995

Budget authorization for FY 1994 and FY 1995 will be analyzed following the taxonomy being developed by NSTC. 


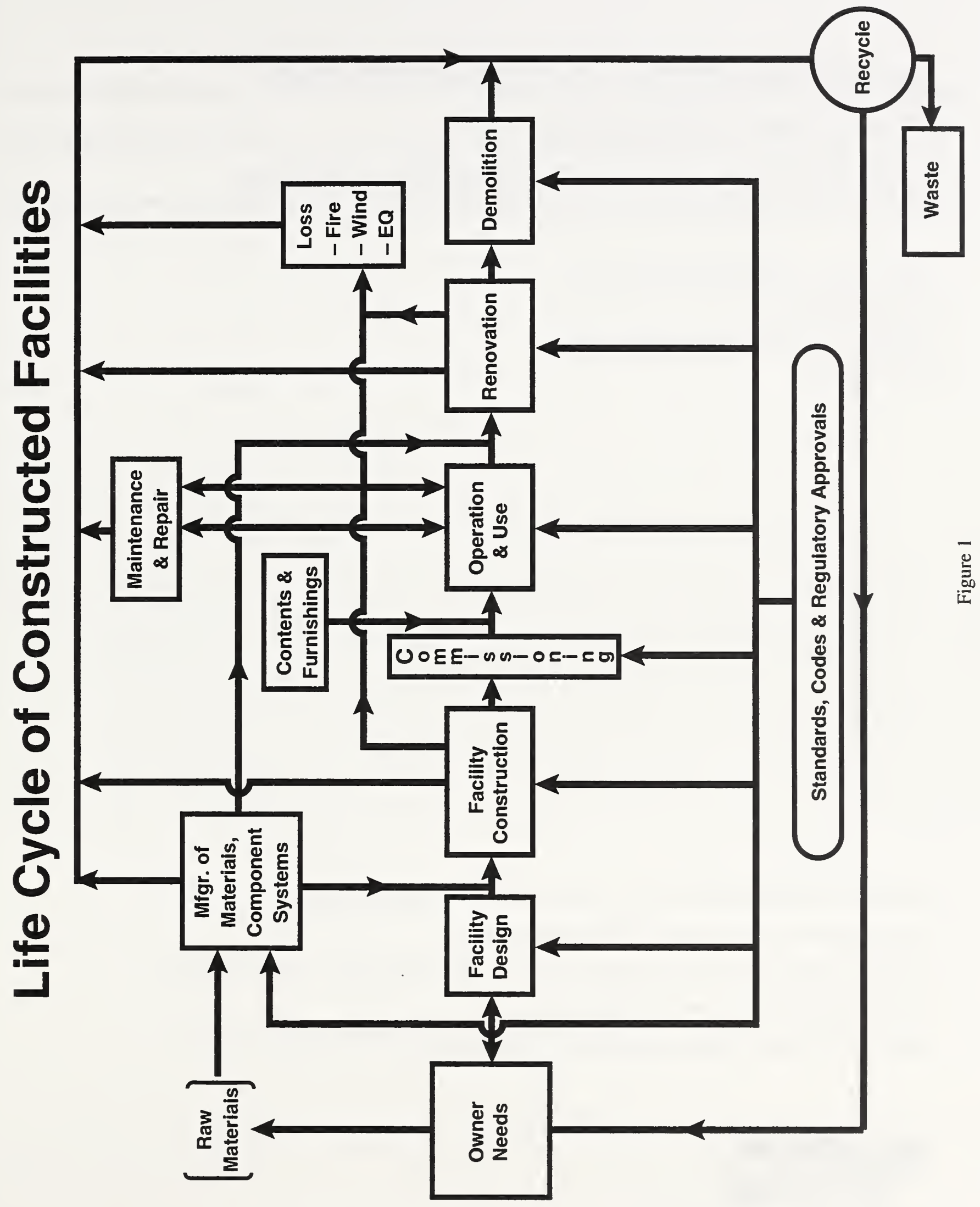




\section{Innovation in the U.S. Construction Industry:} An Essential Component for

\section{America's Economic Prosperity and Well-Being}

A Construction Industry White Paper

Presented by the Civil Engineering Research Foundation April 28, 1994

Based on a joint session held April 5, 1994, in Washington, D.C., involving the White House Office of Science and Technology Policy; the Subcommittee on Construction and Building, Committee on Civilian Industry Technology of the National Science and Technology Council; and civil engineering construction leaders from industry, academe, and the public sector.

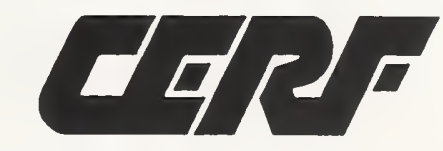

1015 15th Street, N.W., Suite 600 Washington, D.C. 20005 
Al. 2 


\author{
INNOVATION IN THE U.S. CONSTRUCTION INDUSTRY: AN ESSENTIAL \\ COMPONENT FOR AMERICA'S ECONOMIC PROSPERITY AND WELL-BEING
}

\title{
A CONSTRUCTION INDUSTRY "WHITE PAPER"
}

\section{Overview/Objective}

In this "white paper" leaders in the construction industry strongly endorse the Clinton Administration's recognition of the construction industry as one of the principal determinants of the nation's prosperity and well-being, as well as the Administration's focus on Federalprivate sector initiatives to substantially enhance the productivity and competitiveness of the industry, at home and abroad. This paper presents to the Administration an "industry leadership" perspective of methods and means that, if jointly supported and implemented by the public and private sector, promise to transform the construction sector into the hightechnology/high skill sector America requires. These methods and means are prerequisites for effective revitalization of the nation's aging infrastructure, for enabling safe, highly efficient, user-friendly, and affordable constructed facilities (private and public infrastructure and housing) and construction practices that are both environmentally sound and sustainable. The proposed action agenda outlined herein derives from the Civil Engineering Research Foundation's recent construction industry leaders-Federal sector dialogue session with representatives from the White House staff as well as the members of the Construction and Building subcommittee, Committee on Civilian Industrial Technology of the National Science and Technology Council. As noted, this session was initiated by the Civil Engineering Research Foundation (CERF), the research affiliate of the American Society of Civil Engineers (ASCE).

Construction industry leaders are greatly encouraged by the fact that the construction sector has been viewed from the beginning of this Administration as a sector where $\mathrm{R} \& \mathrm{D} /$ innovation is essential and as a sector with the potential to significantly benefit the nation. They are particularly appreciative of the already completed actions the Administration has undertaken to assist the construction sector, including:

- designating buildings and construction as one of five explicit "advanced manufacturing" technologies;

- establishing the subcommittee on Construction and Building within the Committee on Civilian Industrial Technology of the National Science and Technology Council (NSTC); and

- establishing primary contact with the Civil Engineering Research Foundation (CERF) as the means for dialogue with the construction industry.

They likewise recognize both the need and the imperative to act now, in order to respond to the very significant efforts underway in Western Europe and Japan and to benefit both the construction sector and, most importantly, the nation. As in other U.S. industries, 
many fundamental discoveries related to construction and civil engineering have emerged from American universities and laboratories, but have been implemented elsewhere due to pervasive barriers to technology transfer and innovation.

Construction industry leaders look forward to the initiation of a robust construction industry-Federal government cooperative initiative aimed at fundamentally improving U.S. capabilities to encourage and adopt innovation. In this spirit they offer in this "white paper" both as a perspective on the industry and as the outline of a program for change, a program that they believe can play an important role in helping revitalize America's infrastructure, enhance economic prosperity, and improve the health and well-being of all Americans through affordable and environmentally appropriate innovative technologies and processes.

\section{The Impact of Construction in the United States}

Construction and construction-related activities are major players in the U.S. economy, employing over 6 million people and comprising roughly 13 percent of current Gross Domestic Product (GDP). Few Americans realize that it is the nation's largest manufacturing activity! While there are large firms, construction activity in the United States is dominated by hundreds of thousands of small firms. These many firms, in toto, provide the nation with the professional and technical skills and services that enable the creation of constructed facilities and renewal of infrastructure.

Constructed facilities comprise the broad category of man-made facilities that are essential for a modern industrial society to function effectively and provide an acceptable quality of life for its citizens. These facilities constitute the national "infrastructure." The U.S. infrastructure, whether public or private, including utilities, roads, bridges, railroads, ports and airports, homes, schools, hospitals and factories, is held captive to the innovation, or lack thereof, in the design and construction sector. Construction therefore truly impacts all aspects of the U.S. economy! Clearly, constructed facilities enable/provide us with many essential functions, such as:

$\begin{array}{ll}\sqrt{ } & \text { workplaces } \\ \sqrt{ } & \text { transportation } \\ \sqrt{ } & \text { communications }\end{array}$

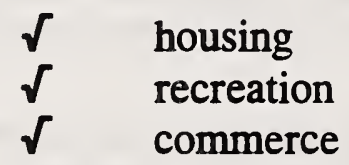

These facilities, in turn, are made possible or are impacted by many factors, including:

$\begin{array}{llll}\checkmark & \text { construction materials/methods } & \checkmark & \text { operations/maintenance } \\ \checkmark & \text { automation/robotics } & \checkmark & \text { renewal engineering } \\ \sqrt{ } & \text { environmental issues } & \checkmark & \text { construction work force skills }\end{array}$

The cost of any manufactured product or service is directly impacted by the construction industry! This occurs at production site facilities, in the national transportation network, in the quality of communications facilities, in sum, at every stage of the production 
process, from creation to disposal. It is clear that the United States cannot afford less than excellence in its constructed facilities as it poises itself to enter the 21 st Century and an increasingly complex and challenging international arena.

Constructed facilities are clearly essential for all aspects of human activity in the United States. The efficiency and the quality of America's constructed facilities must be of paramount concern for they truly determine the quality, efficiency and effectiveness of economic activity and, hence, relative competitiveness in the global marketplace. Moreover, they determine the relative quality of life Americans experience every day, whether at work, at home or at play. The construction sector is, for example:

- a major employer of the nation's work force

- a major consumer of raw materials

- a key to environmental well-being, associated with $1 / 3$ of all energy ( $2 / 3$ of all electricity)

- a key to the nation's work environment, work productivity, safety and health

- a global competitor with international market share

No other manufacturing sector has as pervasive an impact on U.S. economic activity as construction does.

The industry's fragmentation is well-known! Over 80 percent of firms are very small with less than 10 employees; two-thirds have fewer than five. This factor may be partly responsible for the relative difficulty in the past of introducing technological innovations into practice in construction; this is now being resolved with the creation of the Civil Engineering Research Foundation (CERF) as the industry's "facilitator/coordinator/integrator" for R\&D and innovative technologies. Only a few firms have been capable of conducting significant R\&D. Moreover, no firm in the construction sector has been able to absorb the risk inherent in the pursuit and development of innovation. As a consequence, the construction sector currently lags other business sectors in R\&D investment, as indicated below:

Sector Annual Industry R\&D Investment (\%)

Electrical/Electronics

Telecommunications

4.7

Aerospace

4.1

Chemicals

3.8

Automotive

3.4

Construction

U.S. Average 
This can and must change! Innovation in constructed facilities and infrastructure renewal will provide significant national benefits! This will occur because of:

$\checkmark \quad$ improved but affordable materials, leading to reduced materials and energy requirements;

$\checkmark \quad$ reduced maintenance costs over the lifecycle of facilities;

$\sqrt{ }$ improved operational efficiency, manufacturability and durability;

$\sqrt{ }$ healthier, safer and more productive buildings and facilities;

$\sqrt{ }$ improved construction processes/practices;

$\sqrt{ }$ a focus on environmental safeguards and sustainable development; and

$\sqrt{ }$ creation of new businesses and jobs

Innovation in manufacturing processes, materials, design, procurement and costing practices have transformed many U.S. industries, making them more productive as national and global competitors. The construction sector is poised to do likewise.

\section{A Program for Change}

The recent (April 5-6, 1994) initial dialogue between industry leaders and key members of the White House staff, principal Federal agency leaders with construction-related responsibilities, and the members of the National Science and Technology Council (NSTC) subcommittee on Construction and Building (a Committee on Civilian Industrial Technology subcommittee) produced recommendations about methods and means for change that are challenging but achievable from both a technical and an implementation perspective.

The development and use of a process that is capable of encouraging and overseeing innovation in the construction industry is essential. Four components are integral to this process, namely:

- clear and achievable goals;

- appropriate implementation methods and means;

- a viable initial user (customer); and

- incentives and recognition

With respect to goals, construction industry leaders strongly endorse the ambitious goals recently established by the NSTC subcommittee on Construction and Building. These goals include:

- 50 percent reduction in project delivery time;

- 50 percent reduction in operations/maintenance costs;

- 30 percent increase in facility comfort \& productivity;

- 50 percent fewer building-related illnesses and accidents;

- $\quad 50$ percent less waste and pollution; 
50 percent greater durability and flexibility; and

50 percent reduction in job-related illness and accidents for construction workers

A more detailed industry leaders' perspective on these goals is attached in the form of two enclosures to this "white paper." This perspective notes, among other things, the formidable procedures for construction innovation already in place in Japan and France.

Achievement of these ambitious goals will translate, most importantly, into more affordable constructed facilities, including infrastructure and housing. Timing, however, is critical; the joint establishment (by the NSTC subcommittee and industry leaders) of specific timelines for achievement of these goals, based on the relative priority of each goal and its potential impact, is therefore necessary. Development of both short and longer term timelines, ranging from between two and five years to, perhaps, the end of this decade, appears reasonable. The U.S. construction industry must enter the 21 st Century as a world leader in innovation!

Industry leaders commend the Administration for its active role in establishing and emphasizing specific means for public-private sector cooperation. The growing Advanced Technology Program (ATP) and Manufacturing Extension Program (MEP) of the Department of Commerce (through the National Institute of Standards and Technology), the Technology Reinvestment Program (TRP) and the Corps of Engineers' Construction Productivity Advancement Program (CPAR) provide significant promise for commercial R\&D and "dualuse" technology development. Other means, not currently authorized, appear equally promising and should be given careful attention. These include the "set-aside" of a specified percentage of annual U.S. construction volume for R\&D and diffusion of innovative technologies into wide-spread practice. This procedure is already in use in several European countries.

A fundamentally important aspect of this process is the active involvement of the federal sector as first user/customer. "Proof of concept" is a sine qua non for adoption of innovation in any sector; construction is no exception, indeed is even more dependent, given the required assurances of safety and the specter of liability and risk. The federal sector will truly serve the nation through its unique ability to function in this vital role. In this regard, specific legislation or Executive directives may be essential prerequisites. Specific applications have already been identified. These include, for example, precast concrete moment resisting frames, reinforcement steel bond development and use of composites in construction applications ((for example, fiber reinforced plastic (FRP) bridge decks)).

Incentives and recognition comprise the fourth pillar in this process. As noted, the fragmentation, the current procurement methods and the risk adverse environment that characterizes the construction industry have combined to stifle, if not preclude, an innovative perspective. Suitable recognition is therefore essential to promote a climate for innovation. The Malcolm Baldridge Award should be aspired to--the creation of a construction focused 
award is another possibility, perhaps through the subcommittee on Construction and Building. From a more mundane perspective, suitable incentives must be created, for example, appropriate tax code measures, innovative contract delivery systems, life-cycle costing, consideration of proprietary rights, and pre-qualification for innovative technologies, perhaps in a manner similar to the process now established through CERF's Highway Innovative Technology Evaluation Center (HITEC). Continued dialogue between industry leaders and the Office of Science and Technology Policy (OSTP) staff as well as the subcommittee on Construction and Building may lead to even more innovative approaches with respect to recognition and incentives.

The suggested process is in its formative stages. Much remains to be done; the publicprivate sector dialogue that has framed this "white paper" must therefore be given the highest priority within the industry and the Administration. The proposed process has a clear focus and promises to become a vital component of a larger U.S. industrial policy, a policy that will utilize the nation's excellent talents in research and development to enable successful, commercially profitable construction materials, systems and procedures. By doing so, an iterative process can be generated and sustained, perhaps as depicted below, a process that will truly serve the nation in the years to come.

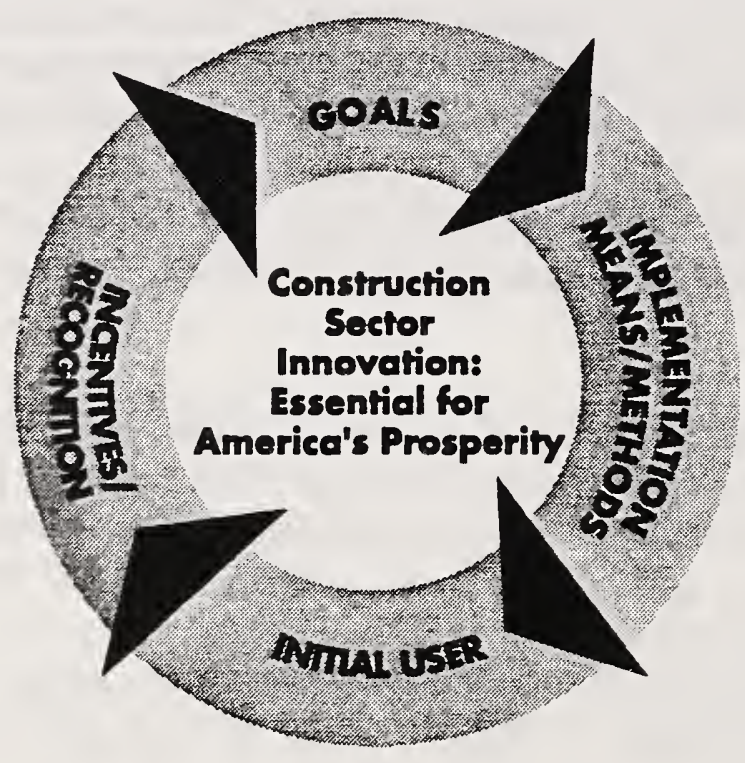


There are, finally, some specific actions that are so important they must be emphasized in this "white paper." These are actions that will empower the process outlined above and, without which, ultimate success will be diminished if not imperiled. They are therefore strongly recommend to the Administration. Specifically, the following actions are recommended:

- reform of Federal procurement practices to explicitly encourage innovation;

- enactment of Federal legislation that provides for the set-aside of a percentage of Federal (or total U.S.) construction funding to promote construction innovation (legislation should include limits on liability);

- $\quad$ create a consensus national "fast track" model (process) for public/private endorsement (approval) of innovation (include code development);

- create tax and other incentives that encourage private sector investment in innovative $R \& D$ and the wide-spread application of such innovation--incentive may be protection of proprietary rights;

- promote the development and use of life-cycle costing in projects and develop standard methodology for application;

- $\quad$ promote the use of new materials, design and construction practices through communication and education regarding innovative R\&D to practitioners, and provide structure and incentives for implementation including the Federal government as first user; and

- identify and work with selected cities/communities/counties/states to incorporate new innovative technologies/practices as a basis for economic development and community revitalization, and obtain Federal waivers and backing as needed (for example, HUD's Empowerment and Enterprise zones).

\section{Conclusions/Recommendations}

The nation's leaders in the construction sector emphatically support the excellent dialogue now emplaced between the industry and the Administration and believe that this dialogue, enabled through Administration leadership, is critical to the continued prosperity and well-being of all Americans. The Administration has "opened the door" as never before to a receptive and committed construction industry leadership. Industry leaders urge expanded dialogue and, most important, the immediate initiation of industry-Federal government cooperative efforts to refine and implement actions suggested herein; joint demonstrations of already developed innovative technologies are recommended as an early cooperative effort, in order to provide high visibility for the benefits derived from such innovation. To use a metaphor that is destined by virtue of innovation to fade rapidly as a real construction sector activity, this "white paper" offers a blueprint for action that the nation cannot afford to see gather dust. The Administration's whole-hearted support, through appropriate legislation and Executive branch actions, will stimulate a construction industry response capable of surmounting the daunting national and global challenges that loom on the threshold of the 21 st Century. 


\section{INDUSTRY PERSPECTIVES/INSIGHTS ON CIT SUBCOMMITTEE PROPOSED GOALS FOR THE CONSTRUCTION SECTOR}

- 50\% Reduction in Project Delivery Time

- Key is "doing it right" the first time; this requires better planning/early goals definition/proper planning and research on the construction process itself

- Requires better integration of design and construction; design/build and design/build/operate have potential

- Performance standards are a must to achieve this reduction

- Requires training, education of work force and demonstrations

- Modify/simplify approval process; too cumbersome and lengthy (in many cases over 20 separate approvals needed)

\section{- $50 \%$ Reduction in Operations/Maintenance (O\&M) Costs}

Reductions in O\&M costs will result primarily from adoption of life-cycle costing, whereby most suitable materials, systems and environmental considerations can be incorporated. Since initial construction costs are estimated at a mere $2 \%$ of the life-cycle costs associated with a facility, a life-cycle cost perspective (including appropriate research) may significantly reduce $O \& M$ costs

- 30\% Increase in Facility Comfort \& Productivity of Occupants

- Has received only modest attention so far

- Performance standards needed for indoor air quality

- Will require improved sensing and control systems/individually controllable

- Will also require improved equipment response to control systems

- Requires improved understanding of health and safety implications

- $50 \%$ Fewer Building-Related Illnesses and Accidents

- Need improved health and safety guidelines

- Focus on ergometrics (people) throughout design/construction process

- $\quad 50 \%$ Less Waste and Pollution

- Expand research on eventual use of recyclable materials

- Inadequate information dissemination regarding unsuitable materials

- $\quad 50 \%$ Greater Durability and Flexibility

- improved durability will result from use of performance specifications

- hinges on improved building materials/equipment and test/evaluation programs

- quality, on-time O\&M is a key factor

- requires visible, viable demonstration projects

- inclusion of all affected parties is essential in demonstration projects to obtain "ownership" and support

- must "publicize" both performance expectations and standards.

- use retrofit of public/private facilities to demonstrate potential improvements

- create government/industry partnerships to facilitate demonstrations; consider national/international competition

- explore/use recyclables to gain durability

- view enclosure materials (windows for example) as an asset, not a liability

- ensure building envelope meets performance specifications (not window alone) 


\section{PERSPECTIVES ON MOVING INNOVATION INTO \\ THE U.S. CONSTRUCTION SECTOR}

\section{Problem}

Develop procedures in the United States that provide incentives for return on construction industry research and development investment. Ensure that the procedures enable efficient transfer of innovation, new technologies, and changed technologies into practice.

\section{Background}

The U.S. practice of separating design and construction into discrete activities with low price as the only selection criteria precludes a return for industry research investment. Companies who invest in research and development are typically penalized because they increase their overhead cost relative to companies who do not invest. Moreover, structural barriers (legal and determination of efficacy) creates risk/reward imbalances which impede effective technology transfer (or preclude such transfer). The U.S. experience stands in sharp contrast to current practices in both Europe and the Far East. Both Japan and France provide instructive insight into processes that appear to function well.

\section{Japan}

\section{$\underline{\text { Process }}$}

- Major construction programs which would benefit from research and innovation are announced with desired performance and function delineated (i.e., national breakwater program, national need to reduce earthquake damage, etc.).

- Research is performed by multiple companies which generates diverse innovation/technology.

- Innovation/technology resulting from research is approved for use by committee of industry, government, and academic experts (generally chaired by an academic) which evaluates the companies' research results. (Additional testing and investigation performed by government laboratories, at company expense, when objectivity is required).

- Companies qualify for bidding based on "experience and expertise," which is demonstrated by research.

- Performance specifications are bid against by prequalified contractors. 
- The companies perform both the design and construction in satisfaction of the performance specifications.

- The most desirable innovations/technologies are transferred to the industry through experience gained on arranged joint ventures.

- An expanding base of companies are prequalified to use a technology/innovation based upon experience rather than research.

- After extended use of the originally developed technology/innovation, the technology/innovation is standardized or codified and specific qualification is not required for its use.

\section{$\underline{\text { Results }}$}

- Prequalification based on expertise stimulates research.

- Design/build allows application of a company's technology/innovation to a project.

- Prequalification based on experience (gained through joint ventures) transfers the technology/innovation.

- Prequalification procurement and design/build delivery system allow a return on industry research investment.

- Evaluation removes efficacy barrier and legal barriers (legal is currently not a significant barrier in Japan).

- French

\section{$\underline{\text { Process }}$}

- Minimum performance and feature specifications are used on selected projects.

- Innovation/technology is evaluated and approved by a standing governmentsponsored committee of experts.

- Design/build contractors are prequalified.

- Price and performance are bid.

- Contract is awarded based upon the "best bid" (that bid offering the greatest value based on price/performance). 
- Long term performance of selected items is warranted.

- Operation/maintenance is sometimes included in the bid.

The government also enters into development agreements for innovation with companies which provide exclusive rights, evaluation, and demonstration. Research investment is recouped through demonstration projects and limited exclusive use.

$\underline{\text { Results }}$

- Best bid selection stimulates research to improve performance.

- Design/build delivery system stimulates innovation by allowing companies to incorporate their innovation into projects.

- Operation and Maintenance (O\&M) component, when used in bidding, quantifies performance over time, yielding a low bid which optimizes the balance between initial cost and life cycle (or a selected time cycle) cost.

- Best bid encourages development of proprietary technology so return on research investment can be achieved.

- Design/build delivery system and development agreements allow a return on research investment.

- Evaluation removes legal (as manifested through insurance requirements) and efficacy barriers.

- Common Characteristics in Japan and France

- Use of design/build for project delivery.

- Prequalification of bidders.

- Limitations on market use of developed technologies.

- Extended guarantees/warranties on performance. (France -- contractual; Japan -social.) 


\section{Possible U.S. Procurement Systems}

A. Identified Technology (needing successful transfer)

- Announce significant project(s) whose construction is limited to a defined technology. Announcement to include desired performance and desired features. (Lead time $+/-24$ months.)

○ Project delivery

\section{Design/Build}

Prequalify contractors based on demonstrated expertise, as well as research and development. (Best suited for new technology or where use of modified technology requires development of construction processes.)

Design, Bid, Build

Selection of A\&E based on team qualification which includes expertise demonstrated by research applying to the requirements of the technology. Contractor selection based on low price. (Best suited where it is a modification of an existing technology so processes do not require extensive development.)

- Prequalify

Design/Build

Prequalify bidders based on team qualifications and limit most qualified bidders to three (3).

Design, Bid, Build

Prequalify construction bidders and limit number to maximum of five (5) most qualified.

- Evaluate utilization of stipulated technology and provide catastrophic insurance (i.e., $\$ 20$ million coverage with $\$ 1$ million deductible -- contractor responsible for deductible amount). 
Design/Build Low Bid (if performance fixed or if bid includes O\&M.) Best Bid (if performance and price bid.)

Unsuccessful bidders receive stipulated compensation. All bidders receive compensation if no award made.

Design, Bid, Build Low Bidder

- No performance guarantee or warranty. Government assumes risk of the preselected technology performance.

B. Development of various and multiple technologies:

- Announce significant project(s) including performance and features desired (lead time $+/-24$ months).

- Design/Build delivery.

- Prequalify bidders based on team qualifications which includes expertise demonstrated by research applying to the requirements of the project(s).

- Limit bidders to three (3).

- Evaluate technologies utilized by bidders and provide catastrophic insurance (i.e., $\$ 20$ million coverage with $\$ 1$ minimum deductible with contractor responsible for deductible).

$\circ \quad$ Award

Low bidder. (if performance fixed or if bid includes O\&M.)

Best bid. (if performance and price bid.)

Unsuccessful bidders receive stipulated compensation for bidding.

Compensation to all bidders if no award made.

- Extended performance guarantee and warranties secured by financial guarantees (bonds) with stipulated penal sum limit (i.e., \$5 million). 
C. Issues

- An open mind approach regarding existing procurement laws would accommodate the suggestions.

- Evaluation should be restricted to life safety and scientific methodology, otherwise good innovations might be precluded. (Some Reflections on Innovation and Invention, George H. Heilmeier: Remarks on Receiving the Founders Award, National Academy of Engineering, Washington, DC, September 29, 1992: "History seems to indicate that breakthroughs are usually the result of a small group of capable people fending off a larger group of equally capable people with a stake in the status quo.")

- Evaluation should be by a panel of experts which includes government, academics and industry. This will enhance technology transfer through exposing experts to innovations and the endorsement for trial use.

- Government's institutional thinking must be changed to that of embracing innovation rather than discouraging it. Otherwise, bureaucrats will always find reasons why new procedures can't possibly be used.

\section{General Observations}

Federal agencies have technical staffs that are capable of evaluating new technology prior to consideration for use and monitoring its performance over time after use. Federal agencies should be participating in technology transfer by encouraging the use of new technology in their projects, or through Federal participation in state and local government projects and selected private projects. Where the new technology is of sufficient magnitude and impact, demonstration projects should be designated and a formalized long term evaluation undertaken. Prior use of a new technology takes major strides in removing the barriers impeding the use of innovation. Successful use on a prior project removes owners' doubts about the risk associated with a new technology, designers' concerns about the standard of care and the contractors' resistance because of unknowns.

All too often in the construction industry we have seen U.S. government supported basic research done at academic institutions in the U.S., but with development and application occurring offshore. The innovation eventually finds its way back to the U.S. and is accepted for use after years of use overseas. This is the challenge we, as civil engineering/construction professionals in the public and private sector must join forces to overcome.

COMNCABIOSTPUStephan 
Department of Commerce, co-chair

Department of Energy, co-chair

Department of Agriculture

Department of Defense

Department of Housing and Urban Development

Department of Health and Human Services

Department of Labor

Department of Transportation

Department of Veterans Affairs

General Services Administration

Environmental Protection Agency

National Science Foundation

National Aeronautics and Space

Administration

Secretariat

Building and Fire Research Laboratory

National Institute of Standards and

Technology

Room B216, Building 226

Gaithersburg, MD 20899

Tel: (301) 975-6865

Fax: (301) 975-4032
Richard Wright

Arthur Rosenfeld

Thomas Hamilton

Thomas Rutherford/Michael $0^{\prime}$ Connor

David Engel/Robert Fuller

Melvin Myers

Thomas Shepich

Thomas Pasko

Lloyd Siegel

David Eakin

Margaret Chu

Kenneth Chong

Murray Hirshbein

Andrew Fowell 
A2. 2 
APPENDIX 3

\section{CONSTRUCTION COMMUNITY ORGANIZATIONS}

1. Owners, Developers and Users

American Hospital Association

Building Owners and Managers Association

Business Roundtable

Construction Industry Institute

Consumers League

Consumer's Union

Facilities Managers

Hotel Motel Owners Association

Low-Income Housing Coalition

Multi-Housing Council

National Association of Housing and Development Officials

National League of Cities

Public Private Venture Association

2. Axchitectural and Engineering Designers

American Institute of Architects

American Lighting Association

American Planning Association

American Psychological Association

American Society of Civil Engineers, Civil Engineering Research Foundation

American Society of Heating, Refrigerating and Air-Conditioning Engineers

American Society of Mechanical Engineers

American Society of Safety Engineers

Institute of Electrical and Electronic Engineers

National Society of Professional Engineers

3. Construction and Contracting Services

American Subcontractors Association

Associated Builders and Contractors

Associated General Contractors

Design-Build Institute

Engineering Contractors Association

Manufactured Housing Institute

National Association of Home Builders

National Construction Safety Executives

National Constructors Association

National Erector's Association

National Roofing Contractors Association

National Utility Contractors Association

Urban Land Institute 
4. Labor

AFL/CIO Building and Construction Trades Council AFL/CIO Occupational Safety and Health Office Asbestos Workers' Union Building and Construction Trades Department Center for Protection of Workers' Rights International Association of Fire Fighters International Brotherhood of Electrical Workers International Brotherhood of Teamsters International Union of Bricklayers International Union of Operating Engineers Iron Workers International Union Painters and Allied Trades International Plasters' and Cement Masons' International Union Roofers and Waterproofers Sheet Metal Workers International United Brotherhood of Carpenters

5. Suppliers of Materials and Equipment Manufacturers

Air Conditioning and Refrigeration Institute

Air Movement and Control Association

Aluminum Association

American Architectural Manufacturers Association

American Building Products - Export - Import Council

American Forest and Paper Association

American Furniture Manufacturers Association

American Iron and Steel Institute

American Textile Manufacturers Association

Association of Home Appliance Manufacturers

Carpet and Rug Institute

Concrete and Masonry Association

Construction Industry Manufacturers Association

Construction Specification Institute

Copper Development Association

Mineral Insulation Manufacturers Association

NAHB Group representing Suppliers

National Electrical Manufacturers Association

National Energy Management Institute

Portland Cement Association

Producers Council

Sweet's Catalog/Dodge Reports

6. Standards Development and Code Enforcement

American Conference of Governmental Industrial Hygienists, Construction Committee American Industrial Hygiene American National Standards Institute, American Society of Testing and Materials 
Council of American Building Officials

National Conference of States on Building Codes and Standards

National Institute of Building Sciences

National Safety Council, Construction Division

7. Health, Environment, Safety, and Emergency Response

American Medical Association

American Public Health Association

Building Security

Fire Marshals Association of North America

International Association of Fire Chiefs

National Emergency Managers Association

National Fire Protection Association

National Sanitation Foundation

Underwriters Laboratories

8. Finance and Insurance

American Bankers Association

Federal National Mortgage Association

Industrial Risk Insurers

Insurance Institute for Property Loss Reduction

Savings and Loan Association Body

9. State and Local Governments

Academy for State and Local Government

American Publics Association

National Association dealing with Workmen's Compensation

National Association of County Engineers,

National Association of Housing and Redevelopment officials

National Association of Planning Officials

National Council of State Housing Agencies

National Governors Association

Public Technology Inc.

U.S. Conference of Mayors

10. Universities and Research Organizations

Advanced Technology for Large Structural Systems

American Society for Engineering Education

Association of Architectural Researchers

Association of Collegiate Schools of Architecture

Association of Schools of Public Health

Building Research Board

Center for Building Performance and Diagnostics

Center for Cement Based Material (Northwestern)

Center for Construction Productivity

Center for Integrated Facilities Engineering,

Construction Industry Institute 
Construction Innovation Forum

Educational Resources Inc.

National Association of Forestry Schools and Colleges

National Center for Earthquake Engineering Research

National Consortium of Housing Research Centers 
